\title{
NOTES BEARING ON VAN BENEDEN, LEUCKART AND SONSINO WHOSE PORTRAITS APPEAR IN PARASITOLOGY, XIV, No. 1.
}

\author{
Portratt-plates XII-XIV.
}

(Continuing the series begun in Vol. XIII.)

By GEORGE H. F. NUTTALL, F.R.S.

(From the Molteno Institute for Research in Parasitology, University of Cambridge.)

\section{Pierre Joseph van Beneden}

1809-1894.

\author{
(Portrait-plate XII.)
}

Pierre Joseph van Beneden was born 19 December, 1809, at Malines, Belgium, and died 8 January, 1894, at Louvain. He graduated in medicine (1831) and became Curator of the Natural History Museum, Louvain, where he became Professor of Zoology and Comparative Anatomy in 1836. Besides doing zoological work of high value which he pursued actively to the end of his life, he established at his own expense in 1843, a marine aquarium, one of the first of its kind. In parasitology he attained great distinction through his investigations upon the biology of parasitic worms and their relation to their hosts, his work Mémoire sur les vers intestinaux (viii +376 pp. 28 pls. $4^{\circ}$ ), published in 1858 , bringing him the "grand prix des Sciences physiques" of the Institut de France. In 1875 he published his results in popular form under the title Les commensaux et les parasites dans le règne animal, as one of the International Science Series, this appearing both in English and German translations. His publications number over 200 and he was joint author with Paul Gervais of a general work on medical zoology in two volumes (1859).

He was the recipient of many distinctions and much esteemed for his high character. He was elected Foreign Corresponding Member of the Royal Society in 1875 and President of the Royal Belgian Academy in 1881. He received the Hon. LL.D. Edinburgh in 1884 and was made Grand Officer of the Order of Leopold in 1886. He left a large family of daughters and one son, 
Edward (1846-1910), who became Professor of Zoology at Liège in 1870 and likewise published contributions to parasitology.

For Biography see Obituary Notice in Proc. Roy. Soc. London, 1895, LVII, p. xx. A portrait appeared in Arch. de Biol. Gand, v. 16. A full Bibliography will be found in Stiles and Hassall (1902) Index Catal. of Med. and Veter. Zool. pp. 85-92; the papers relate to Cestoda, Trematoda, Nematoda, Hirudinea, parasitic Acari and Crustacea, Linguatula, etc. Our portrait is reproduced from a photograph obtained through the courtesy of Prof. J. Bordet of Brussels in 1920.

\section{Rudolph Leuckart}

1822-1898.

\section{(Portrait-plate XIII.)}

Karl Georg Friedrich Rudolph Leuckart was born 7 October, 1822, at Helmstedt, Brunswick, and died 6 February, 1898, at Leipzig. In 1847 he became Privat Docent at Göttingen, in 1850-69 he was Professor of Zoology at Giessen and in 1870-98 he held the like chair at Leipzig. He distinguished himself especially as a helminthologist, being attracted to the subject through the work on parasitic worms carried out by his uncle, Prof. F. S. Leuckart (1794-1843).

His first helminthological work, on Cestodes, appeared in 1848. He wrote on Linguatulidae (Pentastoma, 1857-60), Pupipara, the nematoid worms Attractonema and Sphaerularia, on Trichina spiralis (discovered by Sir James Paget when a student and named by Richard Owen), Echinorhynchus, Strongyloides, and created the class "Sporozoa" among Protozoa. One of his last discoveries was that Lymnaeus periger serves as intermediary host to Distomum hepaticum, a discovery anticipated by a few weeks by Thomas of Oxford, who later became Professor at Christchurch, New Zealand. Much of Leuckart's original work is contained in his Menschliche Parasiten, etc., which went through two editions (1863 and 1876-1901) and was translated into English. Reference to the bibliographies below cited shows the wide range of his activities. His laboratory was a centre of keen research and many well-known parasitologists were his pupils.

For Biography see E. Ray Lankester (1901) in Obituary notices of Fellows of the Royal Society, Roy. Soc. Year-book, reprinted 1904, Pt I, pp. 19-22; R. Blanchard (1898), Arch. de Parasitologie, I, 185-190, with portrait and facsimile letter; V. L. Kellogg (1898), Psyche, Cambridge, Mass. viII, 214-215; F. A. Zuern (1898), Zeitschr. f. Thiermed. Leipzig, II, 235-237. I have drawn from the first two sources.

For complete Bibliography see Leuckart's Festschrift (issued on the 50th anniversary of his professorial career); Stiles and Hassall (1906), Index Catal. of Med. and Veter. Zool. pp. 1078-1088. Our portrait is reproduced from one that appeared in the München. med. Wochenschr. 


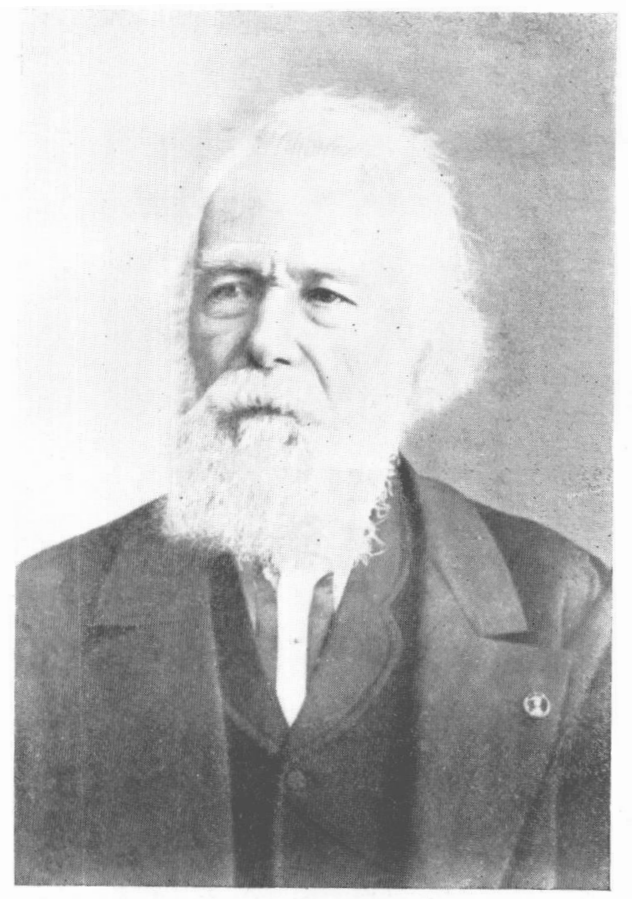

PIERRE JOSEPH VAN BENEDEN

$1809-1894$ 


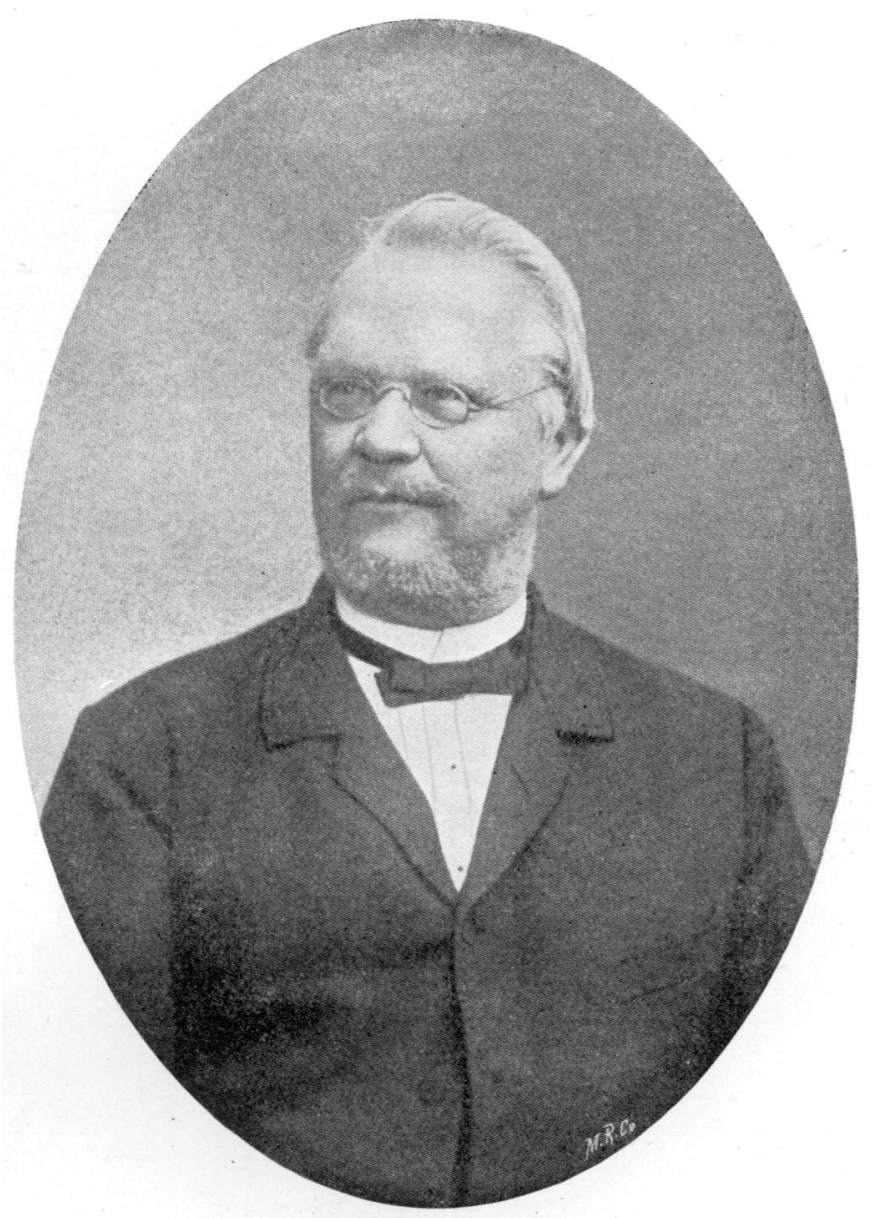

RUDOLPH LEUCKART

$1822-1898$

Separate copies may be obtained from the University Press, Cambridge 


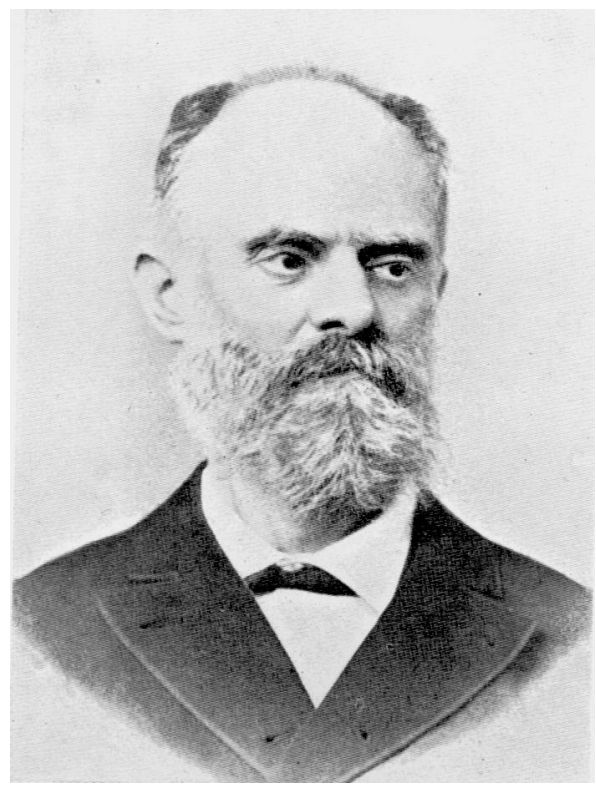

PROSPERO SONSTNO

1835--1901 


\section{ERRATUM.}

Parasitology, xiv, p. 95, last paragraph.

For "Salmon and Stiles" read "Stiles and Hassall." 


\title{
Prospero Sonsino
}

\author{
1835-1901. \\ (Portrait-plate XIV.)
}

Sonsino was born 6 August, 1835, at Tunis, of Italian parents, and died 19 November, 1901, at Montepiano, a village in the Apennines, Tuscany. $\mathrm{He}$ studied medicine at Pisa. In 1860-64 he travelled and practised his profession in Turkey and Asia Minor, then he settled in Florence, where he did public health work and edited a medical journal called the Imparziale, in which some of his papers appeared. In 1873-85 he resided in Egypt, practised and worked under very unfavourable conditions as micrographer to the Khedival Laboratory at Cairo, devoting himself specially to the parasitic worms of man and animals. He next travelled extensively in South America and the Far East as a ship's doctor, and returned to Pisa where he gave free courses in parasitology, revisiting Tunis (1893) and Egypt (1897) before he settled down finally in Montepiano.

As a physician he did heroic work during cholera epidemics in Italy (1865) and subsequently in Egypt. Of his 139 publications, 70 (published in 18741901) relate to helminthology. He laid stress on the importance of helminths as a direct cause and indirect predisposing cause of disease at a time when all too little significance was attached to them by physicians. Sonsino attached much importance to the experimental study of helminthology. He wrote on Schistosomiasis in man and animals, Filaria bancrofti, Ancylostoma duodenale, Distomum hepaticum, and described a number of new and interesting species of helminths with which his name remains linked in the literature.

For a biography of Sonsino see Galli-Valerio (1906-7), Arch. de Parasitol. $\mathrm{XI}, 425-438$, with portrait (herein reproduced) and signature (1893), a portrait on his death bed (1901), a facsimile of a letter, and bibliography; see also bibliography in Salmon and Stiles (1910), Index Catal. of Med. and Vet. Zool. pp. 2204-2211. Sonsino presented a collection of his papers to the writer in 1898, these papers being now in the Library of the Molteno Institute for Research in Parasitology. 


\section{NOTICE.}

A Bibliography on Hookworm Disease of about 450 pages will shortly be ready for distribution as Publication No. 11 of the International Health Board. As the volume will be published in a limited edition, it is hoped that only individuals and institutions especially interested in the subject will apply for copies. Requests should be addressed to

\section{The Rockefeller foundation,}

61 Broadway,

New York City, N. Y.

U.S.A.

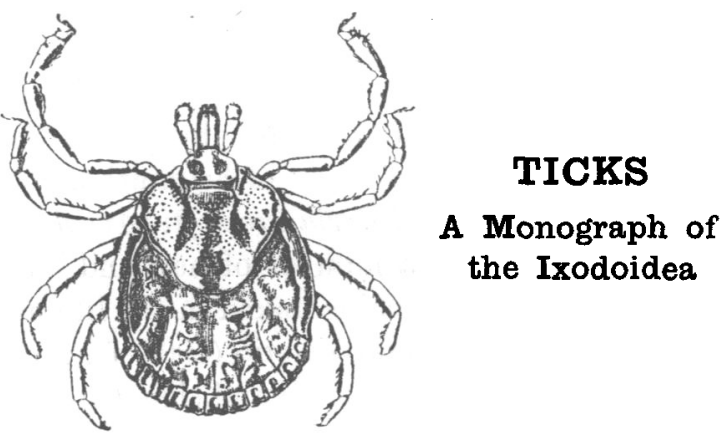

Part I. THE ARgasmaE, viii +104 pp., 116 text-figures and 3 plates. Royal 8vo. 7s. 6d. net. (Appeared 1908.)

Part II. IXODIDAE, THE GENUS IXODES, xix +243 pp., 192 text-figures and 4 plates. Royal 8vo. 14s. net. (1911.) For Bibliography, see below.

Part III. IXODIDAE, THE GENOS HAEMAPHYSALIS, xiii + 202 pp., 144 text-figures aud 6 plates (2 coloured). Royal $8 v 0$. 14s. net. (1915.) For Bibliography, see below.

By

George H. F. Nuttale, F.R.S. and C. Warburton, M.A.

\section{BIBLIOGRAPHY OF THE IXODOIDEA}

Part I by G. H. F. Nuttall, L. E. Robinson and W. F. Cooper. (2004 titles.) $7 s .6 d$. net. (1911.) Not sold separately from Part II of Text as above.

Part II by G. H. F.. Nuttall and L. E. Robinson. (462 titles.) 6s. 6d. net. (1915.) Not sold separately from Part III of Text as above.

N.B. These Bibliographies are an essential part of the work as they contain complete references to authors cited in the text and the references are frequently accompanied by notes in parentheses.

Postage extra on each part.

CAMBRIDGE UNIVERSITY PRESS

Fetter Lane, London, E.C. 4

C, F. CLAY, Manager. 